\title{
PERAN PERTUMBUHAN EKONOMI DALAM MENURUNKAN KEMISKINAN DI TINGKAT PROVINSI DI INDONESIA TAHUN 2004
} 2012

\author{
Denni Setiawan Jayadi
}

\author{
Aloysius Gunadi Bata
}

\section{Program Studi Ilmu Ekonomi dan Studi Pembangunan Fakultas Ekonomi Universitas Atma Jaya Yogyakarta Jalan Babarsari No. 43 Yogyakarta}

\begin{abstract}
Abstrak
Penelitian ini bertujuan untuk mengetahui dan menganalisis peran pertumbuhan ekonomi terhadap penurunan kemiskinan dilihat dari sektoral tahun 2004-2012. Variabel yang digunakan adalah jumlah penduduk miskin sebagai variabel dependen dan PDRB 9 sektor sebagai variabel independen. Data yang digunakan dalam penelitian ini merupakan data sekunder yang diperoleh dari terbitan world data bank. Metode analisis yang digunakan adalah regresi data panel dengan pendekatan model fixed effect. Dalam mengolah data, penulis menggunakan bantuan software Eviews 8.1.

Berdasarkan hasil estimasi di peroleh bahwa secara keseluruhan pertumbuhan ekonomi berpengaruh negatif dan signifikan terhadap kemiskinan di tingkat Provinsi di Indonesia. Selanjutnya dilihat dari segi sektoral ditemukan bahwa variabel sektor pertambangan memiliki pengaruh yang negatif dan signifikan terhadap penurunan kemiskinan. Hal itu disebabkan adanya commodities boom terhadap komoditi hasil tambang. Sehingga sektor pertambangan bukanlah sektor yang menjadi kunci dalam penurunan kemiskinan namun terjadinya commodities boom memiliki pengaruh terhadap penurunan kemiskinan di Provinsi di Indonesia.
\end{abstract}

Kata Kunci : Kemiskinan, PDRB sektoral, pertumbuhan ekonomi, commodities boom. 


\section{PENDAHULUAN}

\subsection{Latar Belakang}

Kemiskinan merupakan salah satu masalah mendasar yang menjadi pusat perhatian pemerintah di negara manapun. Di hampir semua negara berkembang, standar hidup sebagian besar penduduknya cenderung sangat rendah, tidak hanya jika dibandingkan dengan standar hidup orang-orang di negara kaya, namun juga dengan golongan elit di negara mereka sendiri. Standar hidup yang rendah tersebut terwujud salah satunya dalam bentuk tingkat pendapatan yang sangat rendah atau kemiskinan (Todaro, 2006).

Pertumbuhan ekonomi diyakini memiliki pengaruh yang signifikan terhadap penurunan jumlah kemiskinan. Namun demikian pengaruh tersebut dapat saja berbeda antara negara yang satu dengan negara lainnya. Keadaan distribusi pendapatan, jumlah penduduk, urbanisasi memiliki kaitan penting dalam menentukan pengaruh yang terjadi antara pertumbuhan ekonomi dengan penurunan jumlah kemiskinan (Hasan dan Quibria, 2002). Menurut Jonaidi (2012), terdapat hubungan dua arah yang kuat antara pertumbuhan ekonomi dan kemiskinan di Indonesia. Pertumbuhan ekonomi berpengaruh signifikan terhadap pengurangan angka kemiskinan, terutama di daerah perdesaan yang banyak terdapat kantong-kantong kemiskinan. Sebaliknya kemiskinan juga berpengaruh signifikan terhadap pertumbuhan ekonomi.

Penelitian Siregar dan Wahyuniarti (2007) menemukan bahwa pertumbuhan ekonomi berpengaruh negatif dan signifikan terhadap kemiskinan yang artinya kenaikan pertumbuhan ekonomi menurunkan tingkat kemiskinan. Namun pengaruh yang diberikan oleh pertumbuhan ekonomi tidak dapat sepenuhnya menyelesaikan masalah kemiskinan. Penanggulangan kemiskinan membutuhkan pertumbuhan ekonomi yang berkualitas dan berkeadilan Siregar dan Wahyuniarti menyebutkan bahwa pertumbuhan yang berkualitas dan berkeadilan tersebut adalah pertumbuhan yang berpihak pada masyarakat melalui pembangunan sektor industri dan pertanian yang memiliki pengaruh kuat dalam mengurangi kemiskinan.

Indikasi adanya kemungkinan perbedaan pengaruh dari sektor-sektor ekonomi terhadap penurunan tingkat kemiskinan memunculkan berbagai penelitian yang melihat aspek sektoral dari pertumbuhan ekonomi. Berardi dan Marzo (2015) misalnya menemukan bahwa pertumbuhan ekonomi yang dilihat secara sektoral memiliki pengaruh langsung terhadap penurunan jumlah kemiskinan di negaranegara di Afrika, terutama pertumbuhan yang terjadi di sektor pro-poor yang memang didominasi oleh kantong-kantong kemiskinan. Sedangkan Rose, dkk (2013) menemukan bahwa penurunan jumlah kemiskinan di negara Pakistan dipengaruhi secara signifikan oleh pertumbuhan ekonomi yang didasari oleh pertumbuhan pada sektor industri. Adapun Hasan dan Quibria (2002) menemukan bahwa sektor industri di Asia Barat memiliki pengaruh lebih besar dalam penurunan kemiskinan; berbeda dengan Amerika Latin, Asia bagian Selatan, dan 
Afrika dimana sektor pertanian memiliki pengaruh lebih pada penurunan kemiskinan.

Laju pertumbuhan PDB yang melemah tentu akan berpengaruh pada kemampuan pertumbuhan ekonomi untuk mengurangi tingkat kemiskinan. Namun demikian hal ini perlu dikaji lebih jauh terutama dengan melihat dengan lebih detil sektor-sektor ekonomi mana yang mampu menurunkan tingkat kemiskinan. Penelitian yang melihat pengaruh sektoral terhadap penurunan kemiskinan tersebut belum banyak dilakukan khususnya di Indonesia. Oleh karena itu peneliti tertarik untuk meneliti pengaruh dari pertumbuhan ekonomi secara sektoral terhadap tingkat kemiskinan.

\subsection{RumusanMasalah}

Dengan latar belakang masalah di atas, rumusan masalah dalam penelitian ini adalah: Pertumbuhan sektor manakah yang lebih mampu mengurangi kemiskinan di tingkat provinsi di Indonesia tahun 2004-2012?

\subsection{TujuanPenelitian}

Penelitian ini bertujuan untuk mengetahui: Pertumbuhan sektor manakah yang lebih mampu mengurangi kemiskinan di tingkat provinsi di Indonesia tahun 2004-2012.

\section{LANDASAN TEORI}

\subsection{Kemiskinan}

Kemiskinan merupakan suatu kondisi ketidakmampuan secara ekonomi untuk memenuhi standar hidup rata-rata masyarakat di suatu daerah. Fenomena seperti ini biasa terjadi dikarenakan rendahnya pendapatan masyarakat dalam memenuhi kebutuhan pokok baik papan, sandang, maupun pangan dan juga rendahnya kualitas sumber daya manusia itu sendiri. Kemampuan pendapatan yang rendah ini juga akan berdampak pada berkurangnya kemampuan untuk memenuhi standar hidup rata-rata seperti standar kesehatan dan standar pendidikan. Masalah kemiskinan sering terjadi di negara berkembang yang memiliki tingkat jumlah penduduk yang tinggi sehingga terjadi ketidakmerataan kesejahteraan masyarakat yang dapat memicu ketimpangan sosial.

\subsection{Hubungan Pertumbuhan Ekonomi dengan Kemiskinan}

Hubungan antara pertumbuhan ekonomi dengan kemiskinan adalah hubungan yang kompleks dan kontroversional. Secara umum, pertumbuhan ekonomi adalah prakondisi bagi pengurangan kemiskinan. Namun ini tidaklah cukup, berbagai studi telah mencoba menganalisis hubungan antara 
pertumbuhan ekonomi dan kemiskinan yang secara metodologi dapat dikelompokkan menjadi dua (Berardi dan Marzo, 2015). Kelompok pertama berfokus pada hubungan anatara kemiskinan, pertumbuhan pendapatan dan distribusi pendapatan. Penelitian ini merupakan bentuk dari hubungan kemiskinan dengan perekonomian secara mikro dimana pertumbuhan pendapatan dan distribusi pendapatan menjadi idikator dari perekonomian mikro. Sedangkan Kelompok kedua berfokus pada elastisitas kemiskinan terhadap PDB yang merupakan indikator dari perekonomian secara makro. Dalam hal ini, struktur ekonomi adalah elemen penting yang menentukan pengaruh pertumbuhan ekonomi terhadap kemiskinan. Dalam penelitian ini (skripsi) penulis merujuk pada jenis penelitian kedua yaitu berfokus pada pengaruh struktur PDB terhadap tingkat kemiskinan.

\section{METODE PENELITIAN}

\subsection{Jenis, Sumber Data, dan Metode Analisis Data}

Data yang digunakan dalam penelitian ini adalah data sekunder mengenai kemiskinan, PDRB sektoral untuk kurun waktu 2004-2012. Data diperoleh dari Badan Pusat Statistik (BPS) baik di tingkat nasional maupun provinsi dan diakses dari World Bank.

Dalam penelitian ini, penulis tidak memasukkan semua Provinsi yang ada di Indonesia, dikarenakan keterbatasan data pada daerah hasil pemekaran baru yang baru saja dilakukan pemekaran pada tahun 2012. Provinsi yang memiliki keterbatasan data karena merupakan daerah pemekaran baru adalah Kalimantan Utara.

Metode analisis ini mencakup analisis regresi data panel dan uji statistik (uji-t, uji-F, dan $\mathrm{R}^{2}$ ). Model dasar yang dikembangkan dalam penelitian ini adalah sebagai berikut :

$\mathrm{LP}_{\mathrm{it}}=\beta_{0}+\beta_{1} \mathrm{LAGRI}_{\mathrm{it}}+\beta_{2} \mathrm{LIND}_{\mathrm{it}}+\beta_{3} \mathrm{LSER}_{\mathrm{it}}+\beta_{4} \mathrm{LMINE}_{\mathrm{it}}+\beta_{5} \mathrm{LFIN}_{\mathrm{it}}+\beta_{6}$ $\mathrm{LHOT}_{\text {it }}+\beta_{7} \mathrm{LCONS}_{\text {it }}+\beta_{8} \mathrm{LTRANS}_{\mathrm{it}}+\beta_{9} \mathrm{LUTIL}_{\mathrm{it}}+\mu_{\mathrm{it}}$

di mana :

$\begin{array}{ll}\text { LP } & : \text { Log Jumlah penduduk miskin } \\ \text { LAGRI } & : \text { Log PDRB sektor pertanian } \\ \text { LIND } & : \text { LogPDRB sektor industri } \\ \text { LSER } & : \text { Log PDRBsektor jasa } \\ \text { LMINE } & : \text { LogPDRB sektor pertambangan } \\ \text { LFIN } & : \text { LogPDRB sektor transportasi } \\ \text { LHOT } & : \text { LogPDRB sektor konstruksi } \\ \text { LCONS } & : \text { Log PDRBsektor perhotelan } \\ \text { LTRANS } & : \text { LogPDRB sektor Utilities } \\ \text { LUTIL } & : \text { Log PDRBsektor finansial } \\ \mathrm{i} & : \text { cross section } \\ \mathrm{t} & : \text { time series } \\ \beta_{0} & : \text { intercept } \\ \beta_{1}, \beta_{2}, \ldots \text { dst } & : \text { koefisien regresi }\end{array}$




\subsection{Definisi Operasional}

Untuk memperjelas dan memudahkan pemahaman terhadap variabelvariabel yang akan dianalisis dalam penelitian ini, maka perlu dirumuskan definisi operasional sebagai berikut :

1. Kemiskinan

Kemiskinan merupakan jumlah penduduk yang berada di bawah garis kemiskinan di masing-masing provinsi di Indonesia tahun 2004-2012 (dalam bentuk log linear).

2.

PDRB Sektoral

Pengertian PDRB menurut Badan Pusat Statistik yaitu jumlah nilai tambah yang dihasilkan untuk seluruh wilayah usaha dalam suatu wilayah atau merupakan jumlah seluruh nilai barang dan jasa akhir yang dihasilkan seluruh unit ekonomi di suatu wilayah.

\section{HASIL DAN PEMBAHASAN}

Berdasarkan hasil perhitungan, model yang paling tepat digunakan dalam penelitian ini adalah model fixed effect. Adapun hasil estimasi untuk model fixed effect diperlihatkan pada tabel berikut ini:

Tabel 4.1

Hasil Estimasi Fixed Effect dan Random Effect

\begin{tabular}{|c|r|r|r|r|}
\hline \multirow{2}{*}{ variabel } & \multicolumn{2}{|c|}{ fixed effect } & \multicolumn{2}{c|}{ random effect } \\
\cline { 2 - 5 } & Coefficient & $\mathrm{t}-$ Statistic & Coefficient & \multicolumn{1}{c|}{$\mathrm{t}$-Statistic } \\
\hline C & $4,13 * * *$ & 3,09 & $6,05 * * *$ & 1,36 \\
\hline LAGRI & $-0,25$ & $-1,51$ & 0,15 & 1,42 \\
\hline LIND & $0,12 * * *$ & 2,95 & $0,2 * * *$ & 4,82 \\
\hline LSER & 0,17 & 1,27 & 0,1 & 0,78 \\
\hline LMINE & $-0,13 * * *$ & $-4,78$ & $-0,12 * * *$ & $-4,36$ \\
\hline LFIN & $-0,04$ & $-0,58$ & $-0,17 * *$ & $-2,24$ \\
\hline LHOT & $0,33 * *$ & 2,21 & 0,12 & 0,92 \\
\hline LCONS & 0,05 & 0,68 & $-0,07$ & $-0,80$ \\
\hline LTRANS & $-0,04$ & $-0,41$ & $-0,36 * * *$ & $-3,44$ \\
\hline LUTIL & 0,02 & 0,43 & 0,08 & 1,20 \\
\hline
\end{tabular}

Sumber : Lampiran 2 dan 3

Catatan : variabel dependen adalah Log (jumlah penduduk miskin); $* * *=$ signifikan pada $\alpha 1 \%$; ** = signifikan pada $\alpha 5 \%$; $*$ signifikan pada $\alpha 10 \%, \mathrm{~N}=$ 297; $\mathrm{R}^{2}=0,99 ;$ F-statistic $=818,21$ 
Berdasarkan hasil estimasi uji Hausman, diperoleh nilai statistik chi-square $\left(\mathrm{X}^{2}\right)$ hitung sebesar 100,21. Pada tingkat kepercayaan sebesar $(\alpha)=5 \%$, nilai chisquare $\left(\mathrm{X}^{2}\right)$-tabel sebesar 16,92 . Jika dibandingkan maka nilai chi-square $\left(\mathrm{X}^{2}\right)$ hitung sebesar 100,21 lebih besar daripada nilai chi-square $\left(\mathrm{X}^{2}\right)$-tabel sebesar 16,92 yang artinya menolak $\mathrm{H}_{0}$ sehingga model penelitian yang tepat adalah model fixed effect. Dari hasil uji spesifikasi secara keseluruhan, menyatakan bahwa model yang tepat untuk penelitian ini adalah model fixed effect. Selajutnya dilakukan uji statistik yang bertujuan untuk mengetahui tingkat signifikansi dari masing-masing koefisien regresi variabel independen terhadap variabel dependen. Uji statistik yang digunakan meliputi uji-t, uji-F, dan Koefisien determinasi $\left(\mathrm{R}^{2)}\right.$.

Uji t digunakan untuk melihat apakah secara individu variabel independen berpengaruh terhadap variabel dependen. Dalam penelitian ini, uji-t dilakukan dengan menggunakan pendekatan uji dua sisi (two tail test). Berdasarkan hasil regresi diperoleh Berdasarkan hasil regresi data panel dengan menggunakan metode fixed effect untuk variabel yang signifikan adalah variabel LIND, LMINE, dan LHOT dimana variabel LIND dan LMINE signifikan pada tingkat signifikansi $1 \%$ sedangkan variabel LHOT signifikan pada tingkat signifikansi 5\% (lihat Tabel 4.1). Variabel lain dalam penelitian ini tidak signifikan yaitu variabel LAGRI, LFIN, LCONS, LTRANS, dan LUTIL. Sedangkan variabel yang memiliki pengaruh negatif terhadap kemiskinan adalah variabel LAGRI, LMINE, LFIN, dan LTRANS. Variabel LIND, LSER, LHOT, LCONS, dan LUTIL memiliki pengaruh positif terhadap kemiskinan.

Uji F digunakan untuk mengetahui apakah variabel independen secara bersama-sama mempengaruhi variabel dependen. Nilai F-statistik yang diperoleh dengan pendekatan model fixed effect adalah 818,21. Pada tingkat signifikansi $(\alpha)$ sebesar 5\%, nilai F-statistik tersebut lebih besar daripada batas kritisnya (F-tabel) sebesar 1,97 dengan demikian $\mathrm{H}_{0}$ ditolak. Hal ini berarti keseluruhan variabel independen (PDRB 9 Sektor) secara bersama-sama berpengaruh secara signifikan terhadap variabel dependen (tingkat jumlah penduduk miskin di tingkat Provinsi di Indonesia).

Koefisien determinasi $\left(\mathrm{R}^{2}\right)$ digunakan untuk mengukur seberapa besar persentase variasi variabel independen dapat menjelaskan variasi variabel dependen dalam model. Dari hasil regresi data panel dengan model fixed effect diperoleh nilai $\mathrm{R}^{2}$ sebesar 0.99 . Artinya, sebesar $99 \%$ variasi variabel dependen (LP) dapat dijelaskan oleh variasi variabel independen dalam model penelitian. Sisanya sebesar 1\% dijelaskan oleh variasi variabel independen lainnya di luar model penelitian.

\section{PENUTUP}

\subsection{Kesimpulan}

Berdasarkan hasil penelitian dan analisis tentang peran pertumbuhan ekonomi dalam menurunkan kemiskinan di tingkat provinsi di Indonesia tahun 2004-2012, maka diperoleh kesimpulan yang dapat diuraikan sebagai berikut: 
Pada tahun 2004-2012 sebagai akibat dari peningkatan permintaan akan komoditas pertambangan (commodities boom) memiliki pengaruh yang besar terhadap pemberantasan kemiskinan dan signifikan dalam menurunkan angka kemiskinan.

\subsection{Saran}

Berdasarkan uraian yang telah disampaikan pada sub bab sebelumnya, maka saran yang dapat diberikan dari hasil penelitian ini adalah :

1) Walaupun sektor pertambangan memiliki pengaruh paling besar dan signifikan namun sektor pertambangan tidak dapat menjadi ujung tombak dalam strategi pemberantasan kemiskinan karena pertambangan merupakan sektor yang tidak dapat diperbaharui. Namun dengan kebijakan yang tepat serta tindakan tegas pada ekploitasi hasil tambang oleh asing pertambangan merupakan modal awal dalam penanggulangan kemiskinan di Indonesia.

2) Perbaikan kinerja serta keberpihakan sektor pertanian, transportasi, dan finansial dapat menjadi salah satu senjata dalam memberantas kemiskinan.

Bagi penelitian selanjutnya diharapkan dapat menggunakan alat analisis lain serta variabel independen lainnya dalam menganalisis peran pertumbuhan ekonomi dalam menurunkan kemiskinan di tingkat provinsi di Indonesia.

\subsection{Keterbatasan Penelitian}

Keterbatasan dalam penelitian ini adalah periode waktu yang digunakan hanya delapan tahun, akan lebih baik jika series waktunya lebih lama sehingga dapat lebih menjelaskan hubungan pertumbuhan ekonomi dengan kemiskinan di tingkat Provinsi di Indonesia.

\section{DAFTAR PUSTAKA}

\section{a. Buku}

Badan Pusat Statistik, Data dan Informasi Kemiskinan Provinsi, berbagai edisi.

Gujarati, D.N., (2003), "Basic Econometrics", edisi keempat, International Edition, McGraw-Hill, New York.

Gujarati, D.N., (2006), "Dasar-Dasar Ekonometrika”, Edisi Ketiga, Erlangga, Jakarta.

Kuncoro, M., (2006), "Ekonomi Pembangunan : Teori, Masalah dan Kebijakan", Edisi Keempat, Cetakan Pertama, UPP STIM YKPN, Yogyakarta.

Todaro, M.P., dan Smith, S.C., (2006), "Pembangunan Ekonomi", Edisi Kesembilan, Jilid 1, Erlangga, Jakarta.

Widarjono, A., (2013), "Ekonometrika Pengantar dan Aplikasinya”, Edisi Keempat, UPP STIM YKPN, Yogyakarta.

Hill, R.C., Griffiths, W.E., dan Lim, G.C., (2012), "Principles of Econometrics", edisi keempat, Haboken, New Jersey. 
b. Jurnal

Berardi, N., and Marzo, F., (2015), "The Elasticity of Poverty with Respect to Sectoral Growth in Africa", The Review of Income and Wealth DOI: 10.1111/roiw.12203.

Hassan, R., and Quibria, M.G., (2002), "Poverty and Patterns of Growth", ERD Working Paper No.18.

Rose, S., Abbas, S., Faisal, M., and Masood, M., (2013), "Growth-Poverty Lingkages: Does Sectoral Composition Matter for Pakistan?", World Applied Sciences Journal 21 (6), hal. 915 - 919.

Zaman, K., Ahmad, B., Awan, U., Ali, G., and Naseem, I., (2014) "Measuring pro-poor sectoral analysis for Pakistan: trickle down?", Economic Research-Ekonomska Istraživanja, 27(1), hal. 713-728.

Jonaidi, A., (2012), "Analisis Pertumbuhan Ekonomi dan Kemiskinan di Indonesia", Jurnal Kajian Ekonomi, 1(1), hal. 140-164.

Garnaut, R., (2015) "Indonesian's Resources Boom in International Perspective: Policy Dilemmas and Options for Continued Strong Growth", Bulletin of Indonesian Economic Studies, 51(2), hal. 189-212.

\section{c. Referensi yang diakses dari internet.}

Mirza, D.S.,(2012), "Pengaruh Kemiskinan, Pertumbuhan Ekonomi, dan Belanja Modal Terhadap Indeks Pembangunan Manusia di Jawa Tengah Tahun 2006-2009", Economics Development Analysis Journal, diakses dari http://journal.unnes.ac.id/sju/index.php/edaj pada tanggal 8 Agustus 2015.

Siregar, H., dan Wahyuniarti, D., (2012), "Dampak Pertumbuhan Ekonomi Terhadap Penurunan Jumlah Penduduk Miskin", http://pse.litbang.pertanian.go.id/ind/pdffiles/PROS_2008_MAK3.pdf diakses 11 September 2015.

Adhari, A., (2014), "Realitas Pertambangan Indonesia", http://emliindonesia.com/2014/09/realitas-pertambangan-indonesia/ diakses pada 15 desember 2015

Badan Pusat Statistik, "PDRB : metodologi", http://www.bps.go.id/Subjek/view/id/11\#subjekViewTab2 